\title{
MENINGKATAN HASIL BELAJAR SISWA MENGGUNAKAN PEMBELAJARAN KOOPERATIF PROBLEM BASED LEARNING PADA MATERI TRIGONOMETRI DI SMA
}

\author{
Sri Sukwantini \\ SMA Negeri 1 Pontianak \\ Email: sri.sukwantini.z2@gmail.com
}

\begin{abstract}
Dalam pembelajaran matematika materi trigonometri kelas XI MIPA 1 SMA Negeri 1 Pontianak masih banyak yang dibawah KKM terutama dalam menyelesaikan soal-soal. Oleh karena itu perlu suatu upaya untuk meningkatkan hasil belajar materi tersebut, yaitu melalui implementasi pembelajaran kooperatif problem based learning. Penelitian ini bertujuan untuk meningkatkan hasil belajar siswa menggunakan pembelajaran kooperatif problem based learning kelas XI MIPA 1 SMA Negeri 1 Pontianak. Subjek dalam penelitian ini adalah siswa kelas XI MIPA 1 yang berjumlah 34 siswa, seorang guru matematika dan seorang pengamat. Data yang dikumpulkan berupa hasil belajar siswa dan hasil pengamatan guru. Penelitian ini dilakukan dengan dua siklus. Tiap siklus meliputi 4 (empat) tahap yaitu perencanaan, pelaksanaan tindakan, pengamatan observer, dan refleksi. Hasil penelitian menunjukkan (1) ketuntasan belajar siswa pada siklus pertama sebesar $55 \%$ dengan nilai rata-rata 74,5 dan pada siklus kedua sebesar $100 \%$ dengan nilai rata-rata sebesar 95. Skor aktivitas guru pada siklus pertama adalah sebesar 71,9\% dengan predikat cukup, sedangkan pada siklus kedua adalah sebesar 88,3\% dengan predikat sangat baik. Dari data tersebut menunjukkan bahwa pembelajaran kooperatif problem based learning dapat meningkatkan hasil belajar siswa.
\end{abstract}

\section{Keywords: Problem based learning, Trigonometri, SMA}

\section{PENDAHULUAN}

Matematika merupakan ilmu dasar yang mendasari perkembangan ilmu-ilmu lain dan hampir setiap kegiatan manusia berhubungan dengan matematika. Hal itu sejalan dengan ungkapan yang diutarakan Freudenthal (2000:781) yaitu "Mathematics for life on mathematics as a human activities" artinya matematika merupakan sebuah aktivitas yang berlaku dan bermanfaat dalam kehidupan sehari-hari. Oleh karena itu mata pelajaran matematika menjadi satu diantara mata pelajaran yang sangat penting untuk diajarkan di sekolah. Peran penting pelajaran matematika tersebut seharusnya mampu membuat pelajaran matematika menjadi satu diantara mata pelajaran yang menyenangkan dan diminati peserta didik. Namun, sampai saat ini masih banyak peserta didik yang merasa matematika sebagai mata pelajaran yang sulit. Sehingga hal tersebut berdampak pada rendahnya hasil belajar peserta didik.

Matematika merupakan salah satu ilmu dasar untuk melatih berpikir kritis, sistimatis, logis, kreatif dan kemampuan bekerja sama yang efektif. Cara berpikir seperti itu dapat dikembangkan melalui belajar matematika, karena metematika memiliki struktur serta keterkaitan yang kuat dan jelas antar konsepnya sehingga melatih kita terampil berpikir rasional. Konsep matematika secara formal dikenal sejak sekolah dasar sampai keperguruan tinggi. 
Pengenalan konsep matematika dilakukan mulai dari hal sederhana sampai yang kompleks. Selama 18 tahun mengajar peneliti banyak menemukan peserta didik menggunakan konsep yang salah dalam pembelajaran terutama pada materi trigonometri.

Dalam silabus Kurikulum 2013 kelas XI MIPA SMA memiliki 8 buah indikator. Indikator yang harus dicapai dalam pembelajaran yang berkaitan dengan penelitian ini, yaitu : (1) menganalisis rumus jumlah dan selisih trigonometri sehingga dapat membuat kesimpulan mengenai rumus jumlah dan selisih trigonometri dan penerapannya pada masalah nyata, (2) Menyelesaikan solusi dari permasalahan yang berkaitan dengan rumus jumlah dan selisih sinus atau cosinus, (3) menyajikan penyelesaian masalah yang berkaitan dengan rumus jumlah dan selisih sinus atau cosinus, (4) Menganalisis rumus perkalian sudut trigonometri sehingga dapat membuat kesimpulan mengenai rumus perkalian sudut trigonometri, (5) menyajikan solusi dari permasalahan yang berkaitan dengan rumus perkalian sudut trigonometri dan penerapannya pada masalah nyata, (6) Menyajikan penyelesaian masalah yang berkaitan dengan rumus perkalian sudut trigonometri, sehingga dapat membuat kesimpulan mengenai rumus sudut rangkap trigonometri. Namun kenyataan, sebagian besar peserta didik tahun pelajaran 2018/2019 banyak mengalami kesulitan tentang materi trigonometri. Hal ini dibuktikan dengan beberapa sumber informasi sebagai berikut : (1) hasil belajar; (2) wawancara dengan kolega mata pelajaran serumpun; (3) catatan jurnal guru; (4) hasil supervisi kepala sekolah. Keempat sumber data tersebut mengungkapkan beberapa penyebab yang terkait dengan hasil belajar yang diperoleh peserta didik.

Berdasarkan hasil penilaian harian materi trigonometri tahun pelajaran 2018/2019 disajikan rekapitulasi tabel sebagai berikut :

Tabel 1. Rekapitulasi Hasil Nilai Harian Materi Trigonometri Matematika Kelas XI MIPA 1 SMA Negeri 1 Pontianak Tahun Pelajaran 2018/2019

\begin{tabular}{clc}
\hline No & Ragam Data & Skor/Jumlah \\
\hline $\mathbf{1}$ & Banyak peserta didik yang tuntas (di atas KKM) & 14 \\
\hline $\mathbf{2}$ & Banyak peserta didik yang tidak tuntas (di bawah KKM) & 18 \\
\hline $\mathbf{3}$ & Rata-rata & 67 \\
\hline $\mathbf{4}$ & Skor tertinggi & 97 \\
\hline $\mathbf{5}$ & Skor terendah & 20 \\
\hline $\mathbf{6}$ & Standar Deviasi & 26 \\
\hline
\end{tabular}

\section{Banyak siswa $=32$ orang}

Dari data tabel 1.1 di atas, dapat diuraikan sebagai berikut. Banyak peserta didik yang tuntas hanya 14 siswa dari 32 siswa sekitar $44 \%$ tergolong rendah ini disebabkan tidak adanya minat belajar siswa. Rata-rata nilai dari materi logika matematika adalah 67. Nilai ini sangat jauh dari kriteria ketuntasan minimal yaitu 76 . Melihat nilai siswa pada tahun lalu, perlu adanya upaya yang dilakukan oleh guru untuk memperoleh nilai diatas kriteria ketuntasan minimal. Sedangkan skor tertinggi 97 dan skor terendah 20, menunjukkan rentang yang sangat jauh berbeda. Perlu dilakukan tindakan agar rentang nilai siswa tidak terlalu jauh berbeda. Skor tertinggi sebesar 97 diperoleh dua orang siswa, yang memang pada saat pembelajaran dua siswa ini menunjukkan partisipasi yang baik dalam pembelajaran. Sedangkan skor terendah sebesar 20, skor terendah ini dimiliki oleh siswa yang memang jarang masuk sekolah dan jarang mengerjakan tugas-tugas sekolah, tidak memperhatikan guru ketika pembelajaran, serta sering duduk pada tempat duduk yang paling pojok dari belakang.

Berdasarkan hasil catatan jurnal guru selama satu bulan terakhir dalam proses 
pembelajaran dikelas ditemukan beberapa hal berikut. Pertama, banyak siswa kurang fokus dalam proses pembelajaran. Kedua, banyak diantara mereka sibuk sendiri, bercanda dengan teman sebangku. Ketiga, keterlibatan dalam proses pembelajaran kurang. Keempat, siswa terlalu tegang dan tidak berani untuk mengemukakan pendapatnya. Ketidakberanian tersebut dapat terjadi dikarenakan takut jawaban yang dikerjakan salah, sehingga ditafsirkan lain oleh temannya.

Dan yang terakhir dari supervisi kepala sekolah dan pengawas satuan pendidikan pada semester lalu, guru/peneliti diberikan masukan bahwa masih kurang terjadi interaksi antara guru dan siswa. Sedangkan siswa dengan siswa juga kurang interaksi sehingga disarankan untuk membuat suatu model pembelajaran yang melibatkan peran aktif siswa. Baik antar sesama siswa maupun antar siswa dengan guru. Memperhatikan kondisi pembelajaran yang telah diungkapkan guru/peneliti, dapat diungkapkan hasil belajar siswa kelas XI MIPA tahun pelajaran 2018/2019 tergolong rendah. Ini disebabkan oleh beberapa hal, antara lain : (1) kurang aktifnya siswa dalam proses pembelajaran; (2) siswa tidak berani mengeluarkan pendapatnya; (3) proses yang dilakukan guru monoton sehingga membosankan bagi siswa. Berdasarkan ketiga hal tersebut, perlu adanya suatu inovasi atau perubahan dalam pembelajaran matematika dalam menekankan siswa berpikir kritis dan mau mengemukakan pendapat. Salah satu nya yaitu pembelajaran berbasis masalah (Problem Based Learning). Dalam pembelajaran ini siswa diajak untuk berpikir kritis, mengungkapkan pendapatnya, dan mereka saling bertanya dan berbagi-bagi informasi. Pembelajaran lebih terpusat pada siswa, sedangkan guru sebagai fasilitator saja.

Menurut Erman Suherman, (dalam Bistari, 2015: 320) menyatakan model pembelajaran berbasis masalah sebagai pola interaksi siswa dengan guru di dalam kelas yang menyangkut strategi, pendekatan, metode dan teknik pembelajaran yang diterapkan dalam pelaksanaan kegiatan belajar mengajar dikelas.

\section{METODE PENELITIAN}

Penelitian ini merupakan Penelitian Tindakan Kelas (PTK) yang dilakukan oleh guru mata pelajaran matematika di SMA Negeri 1 Pontianak. Dalam penelitian ini terdiri dari beberapa siklus, masing-masing siklus terdiri dari 2 kali pertemuan. Setiap tahapan siklus terdiri dari perencanaan tindakan, pelaksanaan tindakan, observasi tindakan, refleksi terhadap tindakan. Hasil refleksi siklus I digunakan untuk perbaikan rencana tindakan pada siklus berikutnya.

Penelitian Tindakan Kelas ini dilaksanakan di kelas XI MIPA 1 SMA Negeri 1 Pontianak kota Pontianak pada semester ganjil tahun pelajaran 2019/2020 pada materi trigonometri matematika. Instrumen dalam penelitian ini adalah : (1) Rencana Pelaksanaan Pembelajaran (RPP), dalam penelitian ini RPP yang digunakan menggunakan metode pembelajaran kooperatif Problem Based Learning (PBL). (2) Perencanaan pembelajaran adalah semua langkah kegiatan pembelajaran dari beberapa siklus yang menggunakan metode pembelajaran kooperatif Problem Based Learning (PBL). (3) Lembar observasi, digunakan sebagai acuan untuk melakukan observasi/pengamatan guna memperoleh data yang diinginkan. Lembar observasi yang digunakan dalam penelitian ini adalah lembar observasi guru dalam proses pembelajaran metematika dengan menggunakan kooperatif Problem Based Learning (PBL). (4) Soal Tes, Digunakan untuk mengetahui peningkatan hasil belajar siswa terhadap materi yang dipelajari. Tes yang diberikan kepada siswa meliputi postest dari setiap siklus. Soal tes yang digunakan dalam penelitian ini adalah tes tertulis yang berbentuk essay. Tes bentuk essay ini digunakan sejalan dengan pendapat Sudjana (1999: 36) yang menyatakan "melalui tes essay ini para siswa dapat mengungkapkan aspek 
kognitif, menyusun dan mengekspresikan gagasannya serta tidak kalah pentingnya adalah guru secara tidak langsung melihat proses berpikir siswa dalam memecahkan masalah". Selain penulisan butir soal juga disusun kisi-kisi, kunci jawaban, dan pedoman penskoran.

Lembar Kerja Peserta Didik (LKPD), Menurut Depdiknas (2008) lembar kerja peserta didik (LKPD) adalah lembaranlembaran berisi tugas yang harus dikerjakan oleh peserta didik. Lembar kegiatan biasanya berupa petunjuk, langkah-langkah untuk menyelesaikan suatu tugas. Menurut Trianto (2009: 222) lembar kerja peserta didik (LKPD) dapat berupa panduan untuk latihan pengembangan aspek kognitif maupun panduan untuk pengembangan semua aspek pembelajaran dalam bentuk panduan eksperimen atau demonstrasi. Trianto (2009: 223) menambahkan bahwa LKPD memuat sekumpulan kegiatan mendasar yang harus dilakukan oleh peserta didik untuk memaksimalkan pemahaman dalam upaya pembentukan kemampuan dasar sesuai indikator pencapaian hasil belajar yang harus ditempuh.

Prosedur penelitian tindakan meliputi empat tahapan, yaitu tahapan perencanaan tindakan, pelaksanaan tindakan, observasi tindakan dan refleksi terhadap tindakan. Langkah-langkah Penelitian yang dilakukan antara lain: (1) Perencanaan Tindakan: a. Membuat Instrument pembelajaran yang terdiri dari Rencana Pelaksanaan Pembelajaran (RPP) yang menggunakan metode pembelajaran kooperatif Problem Based Learning (PBL), b. Membuat Instrument lembar observasi guru dalam pembelajaran matematika menggunakan kooperatif Problem Based Learning (PBL), c. Menyiapkan LKPD untuk membantu siswa memahami materi yang diajarkan, d. Menyusun soal post test untuk mengukur hasil belajar siswa. (2) Pelaksanaan Tindakan, Secara umum kegiatan implementasi tindakan meliputi : pada awal kegiatan siwa diberikan penjelasan singkat tentang tugas yang harus dikerjakan dengan berdiskusi kelompok yang terdidri atas 4 atau 5 orang secara acak. (3) Observasi Tindakan: Kegiatan observasi adalah melakukan monitoring terhadap pelaksanaan tindakan pembelajaran dengan menggunakan kooperatif Problem Based Learning (PBL) dengan menggunakan lembar observasi guru yang telah dibuat kemudian dicatat kejadiankejadian selama pembelajaran berlangsung setelah adanya obsevasi dilakukan evaluasi. (4) Refleksi Terhadap Tindakan: Pada tahap refleksi ini dilakukan dengan cara mendiskusikan masalah hasil yang diperoleh pada tahap observasi. Jika belum memenuhi target, maka penelitian dilanjutkan ke siklus berikutnya dan kelemahan/kekurangan yang terjadi pada siklus sebelumnya di buatkan dalam bentuk laporan untuk mempermudah dalam memperbaikinya serta untuk mengetahui kekurangan maupun kelemahan yang dilakukan. Hasil analisis siklus I diperbaiki pada siklus II sehingga pembelajaran siklus II diharapkan lebih maksimal daripada siklus I. Jenis data yang dikumpulkan dalam proses pembelajaran kooperatif Problem Based Learning yaitu: (1) Hasil observasi guru mengenai proses kegiatan pembelajaran dengan menggunakan pembelajaran kooperatif Problem Based Learning diambil menggunakan lembar observasi guru. (2) Data peningkatan hasil belajar siswa diambil dari data posttest (tes akhir) setelah kegiatan pembelajaran pada setiap siklus. (3) Data hasil Refleksi diri diambil dengan menggunakan laporan. Data hasil Penelitian akan dianalisis secara deskriptif untuk tiap siklus. Hal ini bermanfaat untuk rencana perbaikan pembelajaran pada siklus berikutnya. 


\section{Analisis Pelaksanaan Pembelajaran Dengan Menggunakan Kooperatif Problem Based Learning}

Data pelaksanaan pembelajaran yang terdapat pada lembar observasi guru dalam menggunakan pembelajaran kooperatif Problem Based Learning, catatan saat dilapangan di analisis secara deskriptif untuk setiap siklus. Hal ini bermanfaat untuk rencana perbaikan pembelajaran pada siklus berikutnya.

Untuk menentukan keberhasilan penerapan menggunakan kooperatif Problem Based Learning ini digunakan tingkat keberhasilan tindakan (tingkat penguasaan). Menurut Ngalim Purwanto (dalam kumaidah: 61-62) tingkat keberhasilan tindakan (tingkat penguasaan) disajikan dalam tabel berikut:

Tabel 2. Tingkat Penguasaan (Tingkat Keberhasilan Tindakan)

\begin{tabular}{cccc}
\hline Tingkat Penguasaan & Nilai Huruf & Bobot & Predikat \\
\hline $\mathbf{8 6 \%}-\mathbf{1 0 0 \%}$ & A & 4 & Sangat Baik \\
\hline $\mathbf{7 6 \%}-\mathbf{8 5 \%}$ & B & 3 & Baik \\
\hline $\mathbf{6 0 \%}-\mathbf{7 5 \%}$ & C & 2 & Cukup \\
\hline $\mathbf{5 5 \%}-\mathbf{5 9 \%}$ & D & 1 & Kurang \\
\hline$<\mathbf{5 4 \%}$ & E & 0 & Sangat Kurang \\
\hline
\end{tabular}

\section{Analisis Peningkatan Hasil Belajar Siswa}

Post test adalah data utama dalam melihat peningkatan hasil belajar siswa dalam pembelajaran menggunakan kooperatif problem Based Learning. Maksud analisis peningkatan hasil belajar siswa dalam penelitian ini adalah siswa yang mengikuti post test pada siklus 1 dan siklus 2. Untuk mengetahui tingkat keberhasilan dari hasil post test didasarkan pada kriteria penilaian menurut Oemar Hamalik, sebagai berikut :

Tabel 3. Kriteria Penilaian

\begin{tabular}{ccccc}
\hline Nilai Huruf & Angka 0-4 & Angka 0-100 & Angka 0-10 & Predikat \\
\hline A & 4 & $85-100$ & $8,5-10$ & Sangat Baik \\
\hline B & 3 & $70-84$ & $7,0-8,4$ & Baik \\
\hline C & 2 & $55-69$ & $5,5-6,9$ & Cukup \\
\hline D & 1 & $40-54$ & $4,0-5,4$ & Kurang \\
\hline E & 0 & $0-39$ & $0-3,9$ & Sangat Kurang \\
\hline
\end{tabular}

Indikator keberhasilan Penelitian Tindakan Kelas ini adalah : (1) Dapat dilaksanakan proses kegiatan pembelajaran matematika dengan menggunakan pembelajaran kooperatif Problem Based Learning pada materi logika matematika di kelas XI MIPA 1 SMA Negeri 1 Pontianak secara optimal sehingga semua komponen utama pembelajaran kooperatif Problem Based Learning dapat dilaksanakan untuk mencapai peningkatan skor rerata aktifitas guru pada siklus sesudahnya lebih baik daripada siklus sebelumnya.

Jika rata-rata hasil belajar siswa pada pembelajaran matematika menggunakan pembelajaran kooperatif Problem Based Learning pada materi trigonometri matematika di kelas XI MIPA 1 SMA Negeri 1 Pontianak pada siklus sesudahnya lebih baik dari pada siklus sebelumnya. 


\section{HASIL DAN PEMBAHASAN PENELITIAN}

Pada kondisi awal hasil belajar yang rendah, minat siswa dalam mengikuti pembelajaran matematika masih kurang, siswa belum berani mengajukan pertanyaan, susah berlatih soal, tidak berami mengemukakan pendapat dan kurang aktif.

\section{Siklus 1}

\section{Perencanaan Tindakan}

Dalam tahap perencanaan tindakan ini guru bertindak sebagai peneliti dan hasil yang didapat selama proses pembelajaran adalah Rencana Pelaksanaan Pembelajaran (RPP) dengan menggunakan pembelajaran kooperatif Problem Based Learning (PBL) pada materi pembelajaran "Rumus Rangkap Sudut Trigonometri". Guru sebagai peneliti menentukan seorang observer yang akan mengobserver guru untuk menilai proses pembelajaran yang disampaikan oleh guru dengan menggunakan lembar observasi guru, peneliti memberikan bimbingan khusus kepada observer mengenai proses pembelajaran kooperatif Problem Based Learning (PBL) yang akan dilaksanakan ini.

\section{Pelaksanaan Tindakan}

Kegiatan penelitian untuk siklus 1 dilaksanakan dalam 2 kali pertemuan yaitu pertemuan pertama dilaksanakan pada hari Jumat, tanggal 6 September 2019 jam ke 1-2 sedangkan pertemuan kedua pada hari Senin, tanggal 2019 jam ke 1-2 dengan masing-masing pertemuan berlangsung selama $2 \times 45$ menit. Dalam penelitian siklus 1 ini peneliti melaksanakan pembelajaran pada kompetensi dasar membedakan penggunaan jumlah dan selisih sinus dan kosinus serta menyelesaikan masalah yang berkaitan dengan rumus jumlah dan selisih sinus dan kosius.

Pada siklus I pertemuan pertama dengan mempraktekkan pembelajaran kooperatif Problem Based Learning (PBL) ini \pm 10 menit untuk kegiatan awal, \pm 15 menit untuk orientasi siswa pada masalah, \pm 30 menit untuk mengorganisasikan siswa belajar, \pm 15 menit untuk membimbing penyelidikan individu dan kelompok, dan \pm 20 menit untuk mengembangkan dan menyajikan hasil karya, sedangkan untuk pertemuan kedua dilanjutkan dengan \pm 20 menit untuk menganalisa dan mengevaluasi proses pemecahan masalah, \pm 60 menit untuk, dan \pm 10 menit untuk konfirmasi sekaligus kegiatan penutupan. Sehingga jumlah waktu seluruhnya untuk pertemuan pertama dan kedua 180 menit Untuk pelaksanaan tes akhir pembelajaran di siklus 1 dilaksanakan pada pertemuan kedua dengan alokasi waktu \pm 60 menit dengan jumlah siswa yang mengikuti tes akhir pembelajaran berjumlah 35 orang, satu orang tidak mengikuti pembelajaran dikarenakan sakit. Dalam kegiatan belajar mengajar menggunakan pembelajaran kooperatif Problem Based Learning (PBL) peneliti dibantu oleh seorang observer yaitu guru mata pelajaran produktif di SMA Negeri 1 Pontianak.

\section{Pengamatan Tindakan}

Pengamatan dilakukan oleh observer dari awal kegiatan pembelajaran dimulai hingga akhir kegiatan pembelajaran selesai. Dengan fokus pengamatan adalah guru/peneliti untuk mengetahui dan menilai seberapa besar tingkat penguasaan guru dalam menggunakan model pembelajaran kooperatif Problem Based Learning (PBL). Ada beberapa kriteria yang harus diamati oleh observer sesuai dengan isi dalam lembar observasi guru yang telah dipersiapkan sebelumnya. Untuk mengetahui kualitas guru dalam proses pembelajarannya diberikan pedoman penskoran 1-4. Dari hasil observasi ini guru telah melakukan tahapantahapan yang ada dalam RPP pembelajaran matematika menggunakan kooperatif Problem Based Learning (PBL) dengan tingkat penguasaan sebesar $60,5 \%$ tergolong dalam predikat cukup. 


\section{Hasil Tes Siklus 1}

Setelah diadakan pembelajaran dengan menggunakan kooperatif Problem Based Learning (PBL) pada siklus 1 dengan $2 \times$ pertemuan selama 4 jam pelajaran (180 menit), dilakukan tes akhir pembelajaran yang dilaksanakan pada hari senin, tanggal 16
September 2019 dengan alokasi waktu selama \pm 60 menit diikuti oleh 35 siswa kelas XI MIPA 1 , terdapat satu siswa yang tidak mengikuti post test. Sehingga hanya siswa yang terdiri dari 14 orang siswa laki-laki dan 21 orang siswa perempuan, dimana rekapitulasi hasil belajar siswa disaikan dalam tabel berikut:

Tabel 4. Rekapitulasi Hasil Belajar Siswa Kelas XI MIPA 1 Siklus 1

\begin{tabular}{lcc}
\hline Ketercapaian & Jumlah Siswa & Persentase \\
\hline Tuntas Belajar & 16 & $45 \%$ \\
\hline Tidak Tuntas Belajar & 19 & $55 \%$ \\
\hline
\end{tabular}

\section{Analisis dan Refleksi}

Pada tahap ini dilakukan analisis terhadap data-data yang telah diproleh, hasil observasi dan hasil belajar siswa adalah sebagai berikut:

Setelah peneliti melakukan pembelajaran di siklus 1 baik pada pertemuan pertama dan kedua, barulah dapat diketahui sejauh mana kemampuan guru ketika mengajar maupun membimbing siswa dalam menggunakan kooperatif Problem Based Learning (PBL). Berdasarkan hasil pengamatan dan catatan observer di siklus 1 dapat dilihat bahwa pada kegiatan pendahuluan guru dalam memotivasi siswa masih kategori cukup dan diharapkan pembelajaran dikaitkan dengan kehidupan sehari-hari. Pada kegiatan inti, menurut hasil observasi, guru sudah mengkondisikan pembelajaran kelompok, Dalam memotivasi siswa diharapkan guru memberikan kesempatan berpendapat bagi siswa yang kurang aktif, kemudian waktu presentasi setiap kelompok sebaiknya ditentukan agar setiap kelompok dapat menyajikan semaksimal mungkin. Untuk kegiatan tanya jawab sebaiknya guru meminta siswa untuk lebih memperhatikan sesi tanya jawab, agar pada sesi tanya jawab selanjutnya tidak ada lagi pengulangan pertanyaan yang sama. Pada kegiatan penutup, yang masih kurang adalah saat memandu membuat kesimpulan, diharapkan penarikan kesimpulan dibuat dalam bentuk contoh soal sehingga siswa mampu mengingat isi materi yang diajarkan, guru juga tidak memberikan penghargaan kepada kelompok. Secara keseluruhan rerata aktifitas guru didalam kelas, memperoleh penilian yang dapat dikatakan cukup. Hal ini dapat dijadikan sebagai acuan perbaikan pada siklus 2.

Oleh karena itu dengan adanya kendalakendala yang terjadi di dalam kegiatan pembelajaran pada siklus 1 ini, maka guru yang sekaligus peneliti bersama dengan rekan sejawat juga sebagai observer berusaha mencari solusi guna meningkatkan kualitas pembelajaran pada siklus 2 yang belum terlaksana. Atas kesepakatan antara peneliti dan observer ada beberapa hal yang perlu diperhatikan dan ditingkatkan oleh guru untuk pelaksanaan pada siklus 2 nanti, yaitu (1) dalam memotivasi siswa pada kegiatan awal diharapkan guru memotivasi siswa dengan memberikan contoh pada kehitupan sehari-hari; (2) pada kegiatan inti tepatnya fase 1 siswa diminta menggaris bawahi atau menandai materi yang mereka belum pahami; (3) pada saat presentasi diminta siswa setiap kelompok untuk berbicara dan memperhatikan persentasi dari kelompok lain; (4) dalam penarikan kesimpulan guru membimbin siswa dengan memberikan contoh dalam penerapan sehari-hari.

Selain dari aktifitas guru yang dilihat, hasil tes belajar siswa juga menjadi salah satu 
indikator dalam penelitian ini, hasil belajar siswa pada siklus 1 yaitu siswa kelas XI MIPA 1 berjumlah 36 siswa, terdapat satu siswa yang tidak mengikuti tes dikarenakan sakit sehingga dengan jumlah 35 orang siswa, diperoleh hasil dengan jumlah siswa yang tuntas 16 orang dengan persentase $45 \%$ sedangkan 19 orang belum tuntas dengan persentase $55 \%$. Rata-rata hasil belajar siswa siklus 1 didapat 72. Dengan rentang nilai yang jauh berbeda yaitu dengan nilai terendah 45 dan nilai tertinggi 90 secara keseluruhan hasil belajar siswa siklus 1 memiliki predikat cukup. Dengan adanya hasil tersebut guru diharapkan menanamkan konsep yang termuat dalam materi pelajaran yang disampaikan dalam pembelajaran, sehingga siswa yang belum mencapai nilai ketuntasan dapat meningkatkan nilainya pada siklus 2 sedangkan untuk siswa yang sudah tuntas dapat mempertahankan atau bahan dapat meningkatkan lagi nilai pelajaran pada materi disiklus 2 .

\section{Siklus 2}

\section{Perencanaan Tindakan}

Pada siklus 2 ini peneliti membuat rencana pembelajaran berdasarkan hasil refleksi pada siklus 1 yang diperoleh sebelumnya. Semua tahapan kegiatan yang akan dilakukan pada siklus 2 adalah cerminan dari siklus 1 dimana kegiatan yang dianggap belum baik atau belum sempurna akan diperbaiki sedangkan yang sudah baik harus bisa dipertahankan atau bahkan dapat ditingkatkan lagi.

Pada siklus 2 ini diharapkan dalam proses kegiatan pembelajaran menggunakan kooperatif Problem Based Learning dapat meningkatkan hasil belajar siswa dari sebelumnya.

\section{a. Pelaksanaan Tindakan}

Untuk kegiatan penelitian pada siklus 2 hampir sama dengan siklus 1 dimana dalam pelaksanaan siklus 2 dilakukan dalam 2 kali pertemuan yaitu pertemuan pertama pada hari senin, tanggal 7 Oktober 2019 jam ke 2-3 sedangkan pertemuan kedua pada hari Jum'at, tanggal 11 Oktober 2019 jam ke 1-2 dengan masing-masing pertemuan berlangsung selama $2 \times 45$ menit. Dengan kompetensi dasar membedakan penggunaan jumlah dan selisih sinus dan kosinus serta menyelesaikan masalah yang berkaitan dengan rumus jumlah dan selisih sinus dan kosius. Sedangkan untuk sub materi yang dibahas tentang rumus perkalian ke penjumlahan sudut trigonometri.

Pada siklus 2 pertemuan pertama dengan mempraktekkan pembelajaran kooperatif Problem Based Learning (PBL) ini \pm 10 menit untuk kegiatan awal, \pm 15 menit untuk orientasi siswa pada masalah, \pm 30 menit untuk mengorganisasikan siswa belajar, \pm 15 menit untuk membimbing penyelidikan individu dan kelompok, dan \pm 20 menit untuk mengembangkan dan menyajikan hasil karya, sedangkan untuk pertemuan kedua dilanjutkan dengan \pm 45 menit untuk menganalisa dan mengevaluasi proses pemecahan masalah, \pm 30 menit untuk elaborasi, \pm 5 menit konfirmasi dan \pm 10 menit untuk kegiatan akhir. Sehingga jumlah waktu seluruhnya untuk pertemuan pertama dan kedua 180 menit Untuk pelaksanaan tes akhir pembelajaran di siklus 2 dilaksanakan pada pertemuan kedua dengan alokasi waktu \pm 60 menit dengan jumlah siswa yang mengikuti tes akhir pembelajaran berjumlah 34 orang. Dalam Kegiatan belajar mengajar menggunakan pembelajaran kooperatif Problem Based Learning (PBL) peneliti masih tetap dibantu oleh seorang observer yaitu guru mata pelajaran produktif di SMA Negeri 1 Pontianak.

\section{b. Pengamatan Tindakan}

Menurut pengamatan observer, diperoleh hasil bahwa guru sudah mulai menunjukkan hasil yang maksimal dalam kegiatan pembelajaran pada siklus 2. Berdasarkan pantauan dan penilaian observer dengan menggunakan lembar observasi guru yang ada langkah-langkah dalam perencanaan pembelajaran kooperatif Problem Based Learning sudah sebagian besar dilaksanakan 
guru dengan baik, guru sudah memperbaiki kesalahan yang dilakukan pada siklus 1, bahkan beberapa kegiatan sudah terlaksana dengan sangat baik.

Berdasarkan lembar observasi guru yang sudah dipersiapkan sebelumnya, tingkat penguasaan yang di peroleh guru pada siklus 2 ini sebesar $78,00 \%$ artinya tingkat penguasaan guru dalam proses pembelajaran kooperatif Problem Based Learning sudah tergolong predikat baik. Sesuai dengan kriteria yang sudah ditentukan sebelumnya.

\section{Hasil Tes Siklus 2}

Setelah diadakan pembelajaran dengan menggunakan kooperatif Problem Based Learning (PBL) pada siklus 2 dengan $2 \times$ pertemuan selama 4 jam pelajaran (180 menit), dilakukan tes akhir pembelajaran yang dilaksanakan pada hari Senin, tanggal 14 Oktober 2019 dengan alokasi waktu selama \pm 60 menit diikuti oleh siswa kelas XI MIPA 1 yang berjumlah 36 siswa, dimana 2 orang tidak mengikuti post test dikarenakan sakit dan dispensasi mengikuti lomba, sehingga total siswa yang mengikuti post test terdiri dari 12 orang siswa laki-laki dan 22 orang siswa perempuan.

\section{Analisis dan Refleksi}

Pada tahap ini dilakukan analisis terhadap data-data hasil observasi dan hasil belajar siswa dan kegiatan refleksi dilakukan setelah pertemuan kedua siklus 2 berakhir. Dilihat dari hasil observasi guru dan hasil belajar siswa ternyata kedua kegiatan ini mengalami peningkatan kualitas pada kegiatannya masingmasing.

Untuk kegiatan guru pada siklus 2 yang dilihat pada lembar observasi guru memperoleh tingkat penguasaan $78 \%$, dengan predikat baik dari siklus 1 dimana memiliki predikat cukup dengan tingkat penguasaan sebesar $60,5 \%$ artinya ada peningkatan dalam tingkat penguasaan sebesar $17,5 \%$. Sedangkan untuk hasil tes belajar siswa pada siklus 2 ini memiliki rata-rata kelas 98. Dengan rentang nilai yang tidak jauh berbeda yaitu dengan nilai terendah 75 dan nilai tertinggi 100 secara keseluruhan hasil belajar siswa siklus 2 mendapatkan predikat sangat baik. Hasil belajar siswa juga mengalami peningkatan dari siklus 1 ke siklus 2 dimana ada peningkatan dua tingkatan predikat dari cukup sangat baik, maka disimpulkan bahwa penelitian telah selesai di siklus 2 .

\section{Perkembangan Hasil Observasi dan Hasil Belajar Siswa}

Selanjutnya setelah mendapatkan rerata hasil belajar siswa siklus 1 dan siklus 2 maka penulis menganalisis perkembangan hasil belajar siswa berdasarkan nilai individu siswa. Dalam pembahasan ini dikemukakan hasil yang diperoleh pada penelitian tindakan kelas melalui pembelajaran kooperatif Problem Based Learning (PBL) pada materi logika matematika dikelas XI MIPA 1 SMA Negeri 1 Pontianak. Dari data yang diperoleh berdasarkan hasil observasi guru dan hasil belajar siswa menunjukkan adanya peningkatan hasil belajar matematika menggunakan pembelajaran kooperatif Problem Based Learning (PBL) pada materi trigonometri dikelas XI MIPA 1 SMA Negeri 1 Pontianak.

\section{Hasil observasi Guru}

Hasil observasi guru dalam menggunakan kooperatif Problem Based Learning (PBL) pada kedua siklus dapat dilihat pada tabel berikut 
Tabel 5.Rekapitulasi Aktifitas Guru

\begin{tabular}{clcccc}
\hline No & Aktifitas Guru & Siklus 1 & Siklus 2 & Peningkatan & \\
\hline $\mathbf{1}$ & Kegiatan Pendahulan & 13 & 16 & +3 \\
\hline $\mathbf{2}$ & Kegiatan Inti & 47 & 56 & +9 \\
\hline $\mathbf{3}$ & Kegiatan Penutup & 18 & 22 & +4 \\
\hline $\mathbf{4}$ & Lain-lain & 14 & 19 & +5 \\
\hline & Jumlah Skor & 92 & 126 & +21 \\
\hline & Tingkat Penguasaan & $71,9 \%$ & $88,3 \%$ & $+16,41 \%$ \\
\hline
\end{tabular}

Berdasarkan tabel rekapitulasi aktifitas guru selamaberlangsungnya pembelajaran dapat disimpulkan bahwa pada siklus 1 guru telah melakukan tahapan-tahapan yang ada dalam RPP pembelajaran matematika menggunakan kooperatif Problem Based Learning (PBL) dengan skor pada kegiatan pendahuluan sebesar 13, kegiatan inti 47 dan kegiatan akhir 18 dengan jumlah skor sebesar 92, untuk penilaian lainnya memperoleh nilai sebesar 14 poin sehingga jika ditotalkan memperoleh tingkat penguasaan $71,9 \%$ dengan predikat cukup. Sedangkan untuk kegiatan siklus 2 guru sudah melaksanakan langkah-langkah dalam perencanaan pembelajaran kooperatif Problem Based Learning dengan jumlah skor kegiatan awal meningkat 3 poin dari siklus sebelumnya yaitu sebesar 16, kegiatan inti meningkat 9 poin dari siklus sebelumnya yaitu memperoleh skor sebesar 56 poin, untuk kegiatan akhir pada siklus 2 ini mendapatkan skor nilai sebesar 22 dengan peningkatan sebesar 4 poin, untuk lainnya memeroleh nilai sebesar 19 dengan peningkatannya sebesar 5 poin. Artinya pada siklus 2 setiap kegiatan pembelajaran mengalami peningkatan dari siklus pertama. Dimana tingkat penguasaan guru pada siklus 2 ini sebesar 88,3\% dan tergolong predikat baik.

\section{Hasil Belajar Siswa}

Selanjutnya rekapitulasi hasil belajar siswa pada siklus 1 dan 2 dengan menggunakan kooperatif Problem Based Learning (PBL) dapat dilihat pada tabel berikut:

Tabel 6. Rekapitulasi Hasil Belajar Siswa

\begin{tabular}{clccc}
\hline No & \multicolumn{1}{c}{ Ragam data } & Siklus 1 & Siklus 2 & Peningkatan \\
\hline $\mathbf{1}$ & Jumlah Nilai & 2458 & 3155 & +697 \\
\hline $\mathbf{2}$ & Nilai Rata-rata Kelas & 74,5 & 95 & $+20,5$ \\
\hline $\mathbf{3}$ & Jumlah Siswa Yang Tuntas Belajar & 19 & 34 & +15 \\
\hline $\mathbf{4}$ & Persentase Siswa Yang Tuntas & $55 \%$ & $100 \%$ & $+45 \%$ \\
\hline $\mathbf{5}$ & Jumlah Siswa Yang Tidak Tuntas Belajar & 16 & 0 & - \\
\hline $\mathbf{6}$ & Persentase Siswa Yang Tidak Tuntas Belajar & $45 \%$ & 0 & - \\
\hline
\end{tabular}

Tindakan guru dalam melakukan kegiatankegiatan dalam menggunakan kooperatif Problem Based Learning (PBL) sangat berpengaruh terhadap hasil belajar siswa. Dimana pada siklus 1 terdapat 19 orang jumlah siswa yang tuntas dengan persentase $55 \%$ dan
16 orang belum tuntas dengan persentase $45 \%$ dengan rata-rata hasil belajar siswa tergolong kategori cukup yaitu berdasarkan nilai rata-rata kelas sebesar 74,5, sedangkan pada siklus 2 seluruh siswa dinyatakan tuntas dengan persentase $100 \%$ dengan rata-rata hasil belajar 
siswa tergolong sangat baik yaitu berdasarkan nilai rata-rata kelas sebesar 95. Maka diketahui adanya peningkatan hasil belajar dari siklus $1 \mathrm{ke}$ siklus 2 sebesar $45 \%$. Di siklus 2 ini pada hasil belajar siswa seluruhnya mengalami peningkatan.

Secara keseluruhan pada siklus 2 telah terjadi peningkatan baik dari hasil observasi guru dan hasil belajar siswa bandingkan dengan siklus 1, dari hasil yang diperoleh pada siklus 2 dapat disimpulkan bahwa pembelajaran menggunakan kooperatif Problem Based Learning (PBL) pada materi trigonometri dikelas XI MIPA 1 SMA Negeri 1 Pontianak dapat meningkatkan hasil belajar siswa. Hal ini sesuai dengan pendapat Bistari (2015: 328) yang menyatakan Pembelajaran Berbasis Masalah bertujuan untuk memotivasi belajar siswa agar menjadi mandiri, membantu siswa mengembangkan keterampilan berfikir dan keterampilan pemecahan masalah, membuat kemungkinan transfers pengetahuan baru, belajar peranan orang dewasa yang otentik.

\section{SIMPULAN DAN SARAN}

\section{Simpulan}

Setelah dilaksanakan Penelitian Tindakan Kelas dengan menggunakan pembelajaran kooperatif Problem Based Learning (PBL) pada materi trigonometri di kelas XI MIPA 1 SMA Negeri 1 Pontianak, maka dapat diambil kesimpulan sebagai berikut : (1) Proses kegiatan pembelajaran diawali dengan melakukan perencanaan tindakan yang dilakukan menggunakan Rencana Pelaksanaan Pembelajaran dengan menggunakan pembelajaran kooperatif Problem Based Learning (PBL) pada materi Trigonometri di kelas XI MIPA 1 SMA Negeri 1 Pontianak pada siklus 1 dan siklus 2 yang disusun oleh peneliti dengan baik dan sudah di validasi oleh kepala sekolah dan peneliti, dibantu oleh seorang observer yaitu guru mata pelajaran produktif untuk menilai proses pembelajaran. elaksanaan tindakan pada setiap siklus dilakukan dalam 2 kali pertemuan dengan masing-masing pertemuan berlangsung selama $2 \times 45$ menit. Pengamatan tindakan dilakukan setiap siklus baik siklus 1 dan siklus 2 ternyata guru dapat meningkatkan kemampuan mengajar menggunakan pembelajaran kooperatif Problem Based Learning dengan tingkat penguasaan pada siklus 1 sebesar 71,9\% sedangkan untuk siklus 2 sebesar 88,3\%, terjadi peningkatan penguasaan sebesar 16,41\%; (2) Hasil belajar siswa setelah menggunakan pembelajaran kooperatif Problem Based Learning (PBL) pada materi Trigonometri di kelas XI MIPA 1 SMA Negeri 1 Pontianak meningkat sebesar 20,5 dari siklus 1 dan siklus 2 . Hal tersebut dapat dilihat pada peningkatan persentase pada siswa yang tuntas dalam setiap siklus, pada siklus 1 terdapat 19 orang jumlah siswa yang tuntas dengan persentase $55 \%$ dan rata-rata nilai siklus 1 sebesar 72,22 dari jumlah siswa sebesar 35, sedangkan pada siklus 2 seluruh siswa dinyatakan tuntas dengan persentase $100 \%$ dan rata-rata nilai siklus 2 sebesar 93 .

\section{Saran}

Berdasarkan penelitian yang telah dilakukan, terdapat beberapa saran yang peneliti berikan, yaitu : (1) Bagi guru yang ingin menggunakan pembelajaran Kooperatif Problem Based Learning harus disesuaikan dengan materi yang ingin disampaikan, serta melaksanakan prosedur yang telah ditetapkan serta abila ingin menggunakan pembelelajaran Kooperatif Problem Based Learning sebaiknya memberikan informasi terlebih dahulu mengenai pembelajaran Kooperatif Problem Based Learning agar siswa mengerti dan mengetahui apa yang harus mereka lakukan pada saat proses pembelajaran berlangsung; (2) Bagi siswa hendaknya diberikan kesempatan lebih banyak dalam mengemukakan pendapat agar siswa lebih aktif; (3) Bagi peneliti yang ingin melaksanakan model pembelajaran Kooperatif Problem Based Learning dapat menggunakan materi yang berbeda dan melakukan perbaikan dari penelitian sebelumnya; (4) Penggunaan pembelajaran 
Kooperatif Problem Based Learning dapat meningkatkan hasil belajar siswa dengan catatan guru harus benar-benar menjadi moderator jalannya kegiatan belajar mengajar selama model tersebut dilaksanakan.

\section{DAFTAR PUSTAKA}

Bistari. (2015). Mewujudkan Penelitian Tindakan Kelas. Pontianak : PT. Ekadaya Multi Inovasi

Departemen Pendidikan Nasional. (2008). Kamus Besar Bahasa Indonesia. Jakarta: Pusat Bahasa.

Gravemeijer, K. \& Terwel. J. (2000) Hans Freudhental : A Mathematician on
Didactics and Curriculum Theory. Journal of curiculum studies

Kumaidah. (2009). Analisis faktor-faktor yang berhubungan dengan gangguan fungsi paru pada pekerja mabel PT. Kota jati furindo desa suswawal kecamatan molonggo kabupaten jepara. [skripsi]. Semarang: Universitas Diponogoro

Nana, Sudjana. (1999). Penilaian proses hasil belajar mengajar. Bandung: Remaja Roesdakarya

Trianto. (2009). Mendesain model pembelajaran inovatif-progresif, Jakarta: Kencana Prenada Media Grup. 